\title{
Patients' Experiences of Barriers and Facilitators for Adherence to Type 2 Diabetes Mellitus: A Meta-Ethnography
}

\author{
Subha Gomathy Sridharan ${ }^{1}$ Mahati Chittem ${ }^{1}$ Sravannthi Maya ${ }^{1}$
}

1Department of Liberal Arts, Indian Institute of Technology Hyderabad, Kandi, Sangareddy District, Telangana, India

\begin{abstract}
Address for correspondence Mahati Chittem, PhD, Department of Liberal Arts, Indian Institute of Technology Hyderabad, Kandi, Sangareddy District, Telangana 502285, India (e-mail: mahati@iith.ac.in).
\end{abstract}

\begin{abstract}
Keywords

- meta-ethnography

- adherence

- synthesis

Objectives The main purpose of this article is to synthesize qualitative research exploring experiences of the factors that facilitated and hindered adherence among patients with type 2 diabetes mellitus (T2DM).

Methods Twenty-six qualitative studies were purposefully included in the final sample. The Critical Appraisal Skills Program criteria for quality assessment of the studies was conducted. A meta-ethnographic approach proposed by Noblit and Hare (1988) was employed to analyze the studies. Using the "reciprocal translation" process, the authors searched for and consolidated the common themes.

Results Three major themes were observed: (1) psychological determinants comprising illness beliefs, locus of control, and being forgetful; (2) sociocultural determinants of family and community, culture, and financial aspects; and (3) patients' relationship with their physicians.

Discussion The meta-ethnography underlines the importance of cultural nuances in the subjective experiences of the barriers and enablers of diabetes adherence. The findings support the need to include qualitative research methods to develop and evaluate interventions to improve T2DM adherence in patients. Clinical implications of this meta-ethnography include engaging in psychoeducation sessions for patients and caregivers, helping set reminders for patients, introducing communication skills training for healthcare providers, and including female caregivers/patients actively in diabetes care.
\end{abstract}

\section{Introduction}

Patients with type 2 diabetes mellitus (T2DM) may face challenges in adherence mainly because they need to manage multiple health behaviors (i.e., diet, exercise, self-monitoring of blood glucose [SMBG] and medical adherence) simultaneously to maintain their glycemic control. Each of these behaviors comes with their own set of, often competing, psychological, sociocultural, and physiological contexts and complexities. For example, dietary adherence not only includes managing one's calorific and nutritional intake but also their eating habits (e.g., time, frequency), culture and values surrounding food (e.g., eating together versus eating alone), their family's ability to support a potential change to the food tradition, and the foods that are available to them. ${ }^{1,2}$ Similarly, within the context of exercise adherence, factors such as having a comorbid condition (e.g., high blood pressure), multiple or severe injuries, climatic conditions, and low levels of internal locus of control reduce the patients' ability to adhere the exercise regime.,3

As the above research suggests, to understand diabetes self-management, it is crucial to take into account the experiential process of adherence as it is closely linked to the outcome behaviors of diet, exercise, SMBG, and medical 
adherence. One method to achieve a thorough understanding of the experience of managing these behaviors is to use qualitative research techniques as they explore the dynamic, nuanced, and personal accounts of an individual. ${ }^{4-6}$ In spite of the limited qualitative research in diabetes self-management (in comparison to quantitative work), there is established evidence for their ability to delve deeply into the lived experiences of patients' efforts toward adherence, especially in terms of their subjective encounters with the barriers and facilitators of adherence.

More recent research attempted at consolidating qualitative studies with the aim of gaining a better understanding of these experiential aspects of diabetes and to inform future direction of both research and practice. ${ }^{8}$ Using different meta-synthesis techniques, research explored topics such as understanding the relationship between managing T2DM and depression, ${ }^{9}$ culture, ${ }^{10}$ and SMBG among patients. ${ }^{11}$ However, in spite of the strong evidence for exploring factors influencing T2DM adherence through qualitative methodologies, there is no systematic research seeking to understand how these factors act as obstacles/enablers of adherence. Therefore, the current paper will use a meta-synthesis technique, meta-ethnography, with the aim of exploring experiences of the factors that facilitate and hinder adherence among patients with T2DM.

\section{Methods}

\section{Design}

Meta-ethnography works on the principle of interpretivism that focuses on interpreting and synthesizing several research findings exploring the subjective experiences and understandings of individuals exposed to the same phenomenon, event, or circumstances. The current synthesis used the meta-ethnography technique proposed by Noblit and Hare comprising seven steps. ${ }^{12}$ These include (1) getting started: framing a specific research question; (2) deciding what is relevant to the initial interest: finalizing relevant research papers by using a specific set of key terms; (3) reading the studies: carefully identifying the concepts, research design, and methods used in each study; (4) determining how the studies are related: looking for common themes across different studies; (5) translating studies into one another: interpreting and developing shared themes; (6) synthesizing the translation: after arriving at the first order and second order of interpretation and identifying nature of translation, these first and second order of interpretation of each study are synthesized in order to arrive at third order of interpretation; and (7) expressing the synthesis: at the end of the process, the synthesized data are presented in a particular form in order to provide evidence to the reader. Qualitative synthesis in psychology research is increasingly using the Noblit and
Hare $^{12}$ technique owing to its ability to continually transfer ideas, concepts, and metaphors across different studies to preserve the meanings of the primary data while still engaging in the meta-synthesis. ${ }^{13-15}$

\section{Methods of Article Extraction}

The first author conducted the article extraction process. First, the following key terms were used to retrieve data during initial search process: diabetes, T2DM, noninsulin dependent diabetes mellitus, self-management, diabetes self-management, diabetes management, adherence, nonadherence, self-care, self-care activities, patients with type 2 diabetes, patients' reports, patients' experiences, patients' perceptions, patients' beliefs, attitude, diabetes regimen, prescribed regimen, diabetes treatment, lifestyle modification, diet, exercise, physical activity, medical treatment of diabetes, medication taking behavior, medication, oral/insulin agents, insulin administration, insulin dosage, SMBG, barriers, difficulties, obstacles, obstructions, problems, hindrances, impede, facilitators, helpful, ease, enablers, improved, support, qualitative, experiences, subjective, personal, and individual. Using the Boolean operators of "AND" and "OR," the first author combined each keyword with the other to identify relevant articles, which were published in English and from 1998 to 2017, were identified from the databases of PubMed, JSTOR, Science Direct, and Web of Science (WoS) ${ }^{1}$ and from the search engine, Google scholar. Other sources such as library catalogues and other search engines were not used due to resource constraints.

Inclusion criteria for the synthesis were that the study (1) explored barriers and/or facilitators of T2DM adherence; (2) pertained to any or all of the T2DM adherence behaviors of diet, exercise, SMBG, and medication; (3) used a qualitative methodology; and (4) explored patients' experiences. Exclusion criteria were if the study (1) used a quantitative methodology or mixed methods, and (2) used multiple perspectives or those of family, community or the medical professional. In this way, 1,342 articles were identified with one or more of these keywords, of these 108 studies were identified that examined barriers and facilitators of T2DM adherence. Of these, 65 studies were excluded because they were either using a quantitative $(n=60)$ or a mixed method $(n=5)$ approach. Of the remaining 43 studies, 17 studies were excluded because they employed a multiple stakeholder perspective (e.g., family, physician, friends). Therefore, 26 studies exclusively focused on patients' experiences of enablers and barriers of T2DM adherence to diet, exercise, SMBG, and medication that were included in the subsequent steps of the meta-ethnography. - Figure $\mathbf{1}$ provides the Preferred Reporting Items for Systematic Reviews and Meta-Analyses (PRISMA) flowchart, and - Table $\mathbf{1}$ describes the details (i.e., authors, year of publication, country of research, cultural backgrounds of the participants, sample size, study design, analysis, aim(s) of the study) of the final 26 studies.

1 Search strategy for WoS: Keywords were used to identify publications from 1998 to 2017 through the WoS database. In this way, 42 studies were obtained from WoS. Of these, 31 studies were excluded as they used quantitative methods, mixed methods, and/or used multiple stakeholders (e.g., family, physician, friends) approach. Consequently, 11 qualitative studies were included in the meta-ethnography that were extracted from WoS as they explored patients' personal accounts of enablers and barriers of T2DM adherence. 


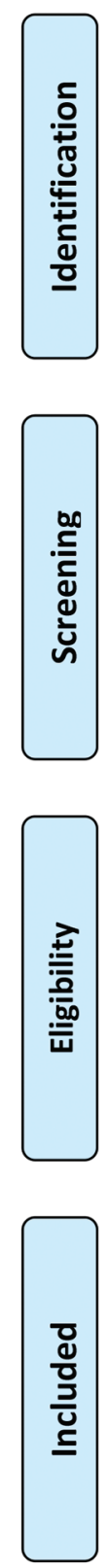

$$
\begin{gathered}
\text { Records identified through database } \\
\text { searching } \\
(n=108)
\end{gathered}
$$
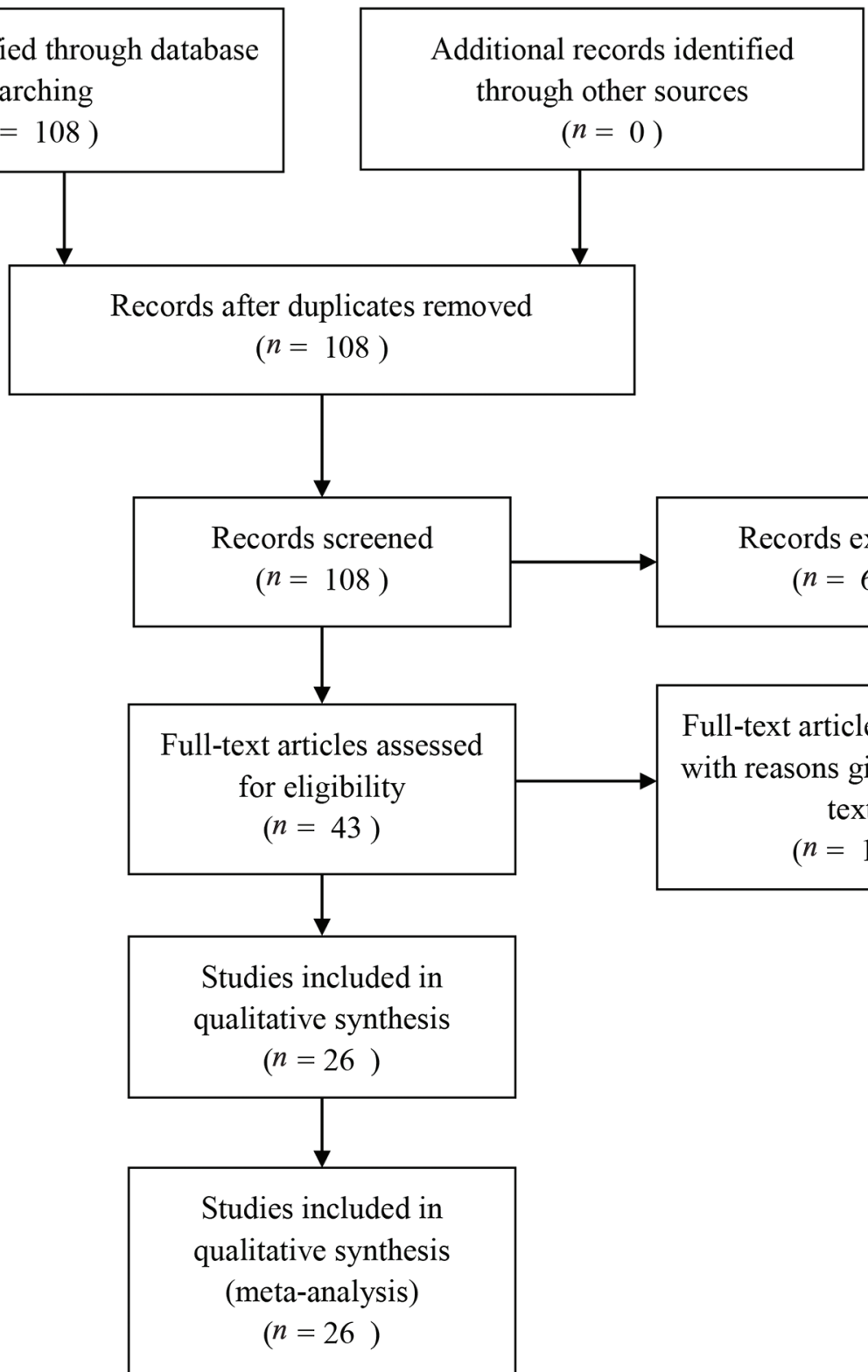

Records excluded $(n=65)$

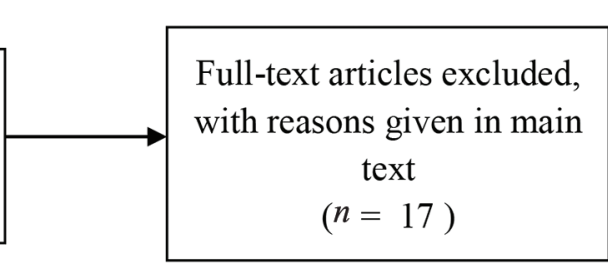

Fig. 1 Preferred Reporting Items for Systematic Reviews and Meta-Analyses (PRISMA) 2009 flow diagram.

The Critical Appraisal Skills Program (CASP) criteria for qualitative research developed by Atkins et al15 were used to check the quality and relevance of these studies. The CASP comprises 13 questions that review two key aspects of a study: (1) the methodological quality and appropriateness and (2) the credibility of the findings. Using the CASP, the authors found that all the 26 shortlisted studies were highly relevant and credible to the purpose of the current meta-ethnography (see - Table 1 for CASP rating of each study).

\section{Data Extraction and Synthesis}

Twenty-six studies were read and re-read carefully by the authors to familiarize themselves with the content and findings of each study. The authors were particularly interested in looking for recurring themes across these studies. To ensure rigor and interpretivism, the current meta-ethnography used reciprocal translation methods as suggested by Noblit and Hare. ${ }^{12} \mathrm{~A}$ method of data interpretation and reciprocal translation comprises a systematic comparison wherein the findings of the first study are compared with the second study 
Table 1 Details of the final 26 studies

\begin{tabular}{|c|c|c|c|c|c|c|}
\hline Author/Year/Country & $\begin{array}{l}\text { Cultural back- } \\
\text { grounds of } \\
\text { participants }\end{array}$ & Sample & Design & Analysis & $\operatorname{Aim}(\mathrm{s})$ of study & $\begin{array}{l}\text { CASP } \\
\text { rating }\end{array}$ \\
\hline $\begin{array}{l}\text { Greenhalgh et al (1998), }{ }^{17} \\
\text { UK }\end{array}$ & $\begin{array}{l}\text { Bangla- } \\
\text { deshi, British, } \\
\text { Afro-Caribbean }\end{array}$ & 50 & $\begin{array}{l}\text { Narratives, } \\
\text { semistructured } \\
\text { interviews, } \\
\text { focus group } \\
\text { interviews, } \\
\text { pile sorting } \\
\text { exercises, and } \\
\text { structured } \\
\text { vignettes }\end{array}$ & $\begin{array}{l}\text { Construct identifi- } \\
\text { cation }\end{array}$ & $\begin{array}{l}\text { To explore the experi- } \\
\text { ence of diabetes }\end{array}$ & $12 / 13$ \\
\hline $\begin{array}{l}\text { Vermeire et al (2003), } \\
\text { Belgium }\end{array}$ & Belgian & 46 & $\begin{array}{l}\text { Focus group } \\
\text { interviews }\end{array}$ & $\begin{array}{l}\text { Qualitative con- } \\
\text { tent analysis }\end{array}$ & $\begin{array}{l}\text { To explore patients' } \\
\text { health beliefs in relation } \\
\text { to their illness, their } \\
\text { communication with } \\
\text { caregivers and the prob- } \\
\text { lems encountered in } \\
\text { adhering to treatment } \\
\text { regimens }\end{array}$ & $12 / 13$ \\
\hline $\begin{array}{l}\text { Vinter-Repalust et al } \\
(2004),{ }^{5} \text { Croatia }\end{array}$ & Croatian & 49 & $\begin{array}{l}\text { Focus group } \\
\text { interviews }\end{array}$ & $\begin{array}{l}\text { Qualitative con- } \\
\text { tent analysis }\end{array}$ & $\begin{array}{l}\text { To explore patients' } \\
\text { attitudes, thoughts, and } \\
\text { fears connected with } \\
\text { their illness; their ex- } \\
\text { pectations of the health } \\
\text { care system; and the } \\
\text { problems they encoun- } \\
\text { tered while adhering to } \\
\text { the therapeutic regimen }\end{array}$ & $13 / 13$ \\
\hline Peel et al (2004), ${ }^{30}$ UK & British & 40 & $\begin{array}{l}\text { Qualitative } \\
\text { repeat-inter- } \\
\text { views }\end{array}$ & Grounded theory & $\begin{array}{l}\text { To explore the pros } \\
\text { and cons of glucose } \\
\text { monitoring from the } \\
\text { patients' perspectives }\end{array}$ & $13 / 13$ \\
\hline Lawton et al (2005), ${ }^{20}$ UK & Pakistani, Indian & 32 & $\begin{array}{l}\text { In-depth inter- } \\
\text { views }\end{array}$ & Grounded theory & $\begin{array}{l}\text { To explore patients' } \\
\text { experiences of, and } \\
\text { views about, undertak- } \\
\text { ing physical activity as } \\
\text { part of their diabetes } \\
\text { self-care }\end{array}$ & $13 / 13$ \\
\hline Lawton et al (2005), ${ }^{20}$ UK & Pakistani, Indian & 32 & $\begin{array}{l}\text { In-depth inter- } \\
\text { views }\end{array}$ & Grounded theory & $\begin{array}{l}\text { To explore patients' } \\
\text { perceptions and expe- } \\
\text { riences of taking oral } \\
\text { hypoglycemic agents } \\
\text { (OHAs) }\end{array}$ & $13 / 13$ \\
\hline $\begin{array}{l}\text { Vermeire et al (2007), }{ }^{6} \\
\text { Belgium, Croatia, Estonia, } \\
\text { France, The Netherlands, } \\
\text { Slovenia, UK }\end{array}$ & $\begin{array}{l}\text { Belgian, Croatian, } \\
\text { Estonian, French, } \\
\text { Dutch, Slovenes, } \\
\text { British }\end{array}$ & 246 & $\begin{array}{l}\text { Focus group } \\
\text { interviews }\end{array}$ & $\begin{array}{l}\text { Grounded theory } \\
\text { followed by quali- } \\
\text { tative synthesis }\end{array}$ & $\begin{array}{l}\text { To assess health beliefs } \\
\text { and obstacles to treat- } \\
\text { ment recommendation/ } \\
\text { adherence }\end{array}$ & $12 / 13$ \\
\hline Peel et al (2007), ${ }^{18}$ UK & British & 18 & $\begin{array}{l}\text { Longitudinal, } \\
\text { qualitative } \\
\text { interviews }\end{array}$ & Thematic analysis & $\begin{array}{l}\text { To explore patients' } \\
\text { views of about } \\
\text { self-monitoring of blood } \\
\text { glucose over time }\end{array}$ & $12 / 13$ \\
\hline Brown et al (2007), ${ }^{24}$ UK & African-Caribbean & 16 & $\begin{array}{l}\text { In-depth inter- } \\
\text { views }\end{array}$ & Thematic analysis & $\begin{array}{l}\text { To gain an understand- } \\
\text { ing of how health beliefs } \\
\text { influence diabetes } \\
\text { management }\end{array}$ & $12 / 13$ \\
\hline $\begin{array}{l}\text { Kokanovic and Manderson } \\
\text { (2007), }{ }^{31} \text { Australia }\end{array}$ & $\begin{array}{l}\text { Greek, Indian, } \\
\text { Chinese, Pacific } \\
\text { Islander }\end{array}$ & 30 & $\begin{array}{l}\text { In-depth inter- } \\
\text { views }\end{array}$ & Thematic analysis & $\begin{array}{l}\text { To explore interactions } \\
\text { with doctors regarding } \\
\text { the diagnosis, treat- } \\
\text { ment, and management } \\
\text { diabetes }\end{array}$ & $13 / 13$ \\
\hline
\end{tabular}


Table 1 (continued)

\begin{tabular}{|c|c|c|c|c|c|c|}
\hline Author/Year/Country & $\begin{array}{l}\text { Cultural back- } \\
\text { grounds of } \\
\text { participants }\end{array}$ & Sample & Design & Analysis & $\operatorname{Aim}(\mathrm{s})$ of study & $\begin{array}{l}\text { CASP } \\
\text { rating }\end{array}$ \\
\hline Lai et al (2007), ${ }^{21}$ Taiwan & Taiwanese & 75 & $\begin{array}{l}\text { In-depth } \\
\text { interviews, } \\
\text { focus group } \\
\text { interviews }\end{array}$ & $\begin{array}{l}\text { Editing and } \\
\text { immersion/ } \\
\text { crystallization }\end{array}$ & $\begin{array}{l}\text { To gain insight into the } \\
\text { perceptions of patients } \\
\text { with diabetes, especial- } \\
\text { ly ideas of the illness } \\
\text { course and perceived } \\
\text { severity, and their } \\
\text { impacts on self-care } \\
\text { behavior }\end{array}$ & $13 / 13$ \\
\hline Lawton et al (2008), ${ }^{23} \mathrm{UK}$ & British & 20 & $\begin{array}{l}\text { Longitudinal, } \\
\text { qualitative } \\
\text { interviews }\end{array}$ & Thematic analysis & $\begin{array}{l}\text { To examine patients' ex- } \\
\text { pectations, perceptions } \\
\text { and experiences of oral } \\
\text { glucose-lowering agents } \\
\text { (OGLAs), including their } \\
\text { reasons for taking/not } \\
\text { taking these drugs }\end{array}$ & $12 / 13$ \\
\hline $\begin{array}{l}\text { Matthews et al (2009), }{ }^{32} \\
\text { USA }\end{array}$ & $\begin{array}{l}\text { North American } \\
\text { (USA) }\end{array}$ & 5 & $\begin{array}{l}\text { Focus group } \\
\text { interviews }\end{array}$ & Thematic analysis & $\begin{array}{l}\text { To explore how adult } \\
\text { women manage their } \\
\text { diabetes }\end{array}$ & $13 / 13$ \\
\hline $\begin{array}{l}\text { Rustveld et al (2009), }{ }^{33} \\
\text { USA }\end{array}$ & Hispanic & 34 & $\begin{array}{l}\text { Focus group } \\
\text { interviews }\end{array}$ & $\begin{array}{l}\text { Framework } \\
\text { analysis }\end{array}$ & $\begin{array}{l}\text { To elicit attitudes, } \\
\text { attributions, and } \\
\text { self-efficacy related to } \\
\text { diabetes self-care }\end{array}$ & $13 / 13$ \\
\hline $\begin{array}{l}\text { Washington and } \\
\text { Wang-Letzkus (2009), }{ }^{25} \\
\text { USA }\end{array}$ & Chinese & 13 & $\begin{array}{l}\text { In-depth inter- } \\
\text { views }\end{array}$ & Thematic analysis & $\begin{array}{l}\text { To explore the self-care } \\
\text { practices patients; to } \\
\text { identify risk factors } \\
\text { related to lifestyle, atti- } \\
\text { tudes and health beliefs }\end{array}$ & $13 / 13$ \\
\hline $\begin{array}{l}\text { Al-Qazaz et al (2011), }{ }^{19} \\
\text { Malaysia }\end{array}$ & Malaysian & 12 & $\begin{array}{l}\text { Semistructured } \\
\text { interviews }\end{array}$ & Content analysis & $\begin{array}{l}\text { To explore patients' ex- } \\
\text { perience and knowledge } \\
\text { about diabetes and } \\
\text { its medication and to } \\
\text { understand the factors } \\
\text { contributing to medica- } \\
\text { tion adherence }\end{array}$ & $13 / 13$ \\
\hline $\begin{array}{l}\text { Shakibazadeh et al } \\
(2011),{ }^{29} \text { Iran }\end{array}$ & Iranian & 43 & $\begin{array}{l}\text { Focus group } \\
\text { interviews }\end{array}$ & $\begin{array}{l}\text { Framework } \\
\text { analysis }\end{array}$ & $\begin{array}{l}\text { To explore a cultural- } \\
\text { ly based experience } \\
\text { regarding the personal } \\
\text { and environmental bar- } \\
\text { riers to and facilitating } \\
\text { factors for diabetes } \\
\text { self-care }\end{array}$ & $13 / 13$ \\
\hline $\begin{array}{l}\text { Tan et al (2012), }{ }^{16} \\
\text { Singapore }\end{array}$ & $\begin{array}{l}\text { Singaporean } \\
\text { Chinese }\end{array}$ & 6 & $\begin{array}{l}\text { Semistructured } \\
\text { interviews }\end{array}$ & Thematic analysis & $\begin{array}{l}\text { To explore how com- } \\
\text { munity-dwelling adults } \\
\text { experience hypogly- } \\
\text { cemia }\end{array}$ & $13 / 13$ \\
\hline $\begin{array}{l}\text { Castro-Sánchez and } \\
\text { Ávila-Ortíz (2013), }{ }^{2} \text { Mexico }\end{array}$ & Mexican & 45 & $\begin{array}{l}\text { Semistructured } \\
\text { interviews }\end{array}$ & Grounded theory & $\begin{array}{l}\text { To describe changes } \\
\text { in eating behavior } \\
\text { and analyze subjects' } \\
\text { perceptions regarding a } \\
\text { diabetes diet }\end{array}$ & $13 / 13$ \\
\hline He et al (2013), ${ }^{26}$ China & Chinese & 17 & $\begin{array}{l}\text { Semistructured } \\
\text { interviews }\end{array}$ & Thematic analysis & $\begin{array}{l}\text { To explore factors } \\
\text { influencing adherence } \\
\text { to exercise }\end{array}$ & $12 / 13$ \\
\hline Zamzam et al (2013), ${ }^{50}$ Iran & Syrian & 12 & $\begin{array}{l}\text { Semistructured } \\
\text { interviews }\end{array}$ & Thematic analysis & $\begin{array}{l}\text { To explore the barriers } \\
\text { to diabetes control } \\
\text { among women }\end{array}$ & $13 / 13$ \\
\hline
\end{tabular}


Table 1 (continued)

\begin{tabular}{|c|c|c|c|c|c|c|}
\hline Author/Year/Country & $\begin{array}{l}\text { Cultural back- } \\
\text { grounds of } \\
\text { participants }\end{array}$ & Sample & Design & Analysis & $\operatorname{Aim}(s)$ of study & $\begin{array}{l}\text { CASP } \\
\text { rating }\end{array}$ \\
\hline $\begin{array}{l}\text { Sherman et al (2014), }{ }^{22} \\
\text { USA }\end{array}$ & African-American & 19 & $\begin{array}{l}\text { In-depth } \\
\text { interview }\end{array}$ & Narrative analysis & $\begin{array}{l}\text { To explore, understand } \\
\text { and describe the lived } \\
\text { experience men, with } \\
\text { emphasis on captur- } \\
\text { ing perceptions of } \\
\text { challenges, facilitators } \\
\text { and perceived barriers } \\
\text { associated with self-care } \\
\text { management }\end{array}$ & $13 / 13$ \\
\hline $\begin{array}{l}\text { Boonsatean et } a^{36} \text { (2015), } \\
\text { Thailand }\end{array}$ & Thai & 19 & $\begin{array}{l}\text { In-depth } \\
\text { interviews }\end{array}$ & $\begin{array}{l}\text { Naturalistic data } \\
\text { processing and } \\
\text { inductive content } \\
\text { analysis }\end{array}$ & $\begin{array}{l}\text { To explore how women } \\
\text { of low socioeconomic } \\
\text { status handle their type } \\
2 \text { diabetes }\end{array}$ & $12 / 13$ \\
\hline $\begin{array}{l}\text { Islam et al (2017), }{ }^{34} \\
\text { Bangladesh }\end{array}$ & Bangladeshi & 12 & $\begin{array}{l}\text { In-depth } \\
\text { interviews }\end{array}$ & $\begin{array}{l}\text { Qualitative con- } \\
\text { tent analysis }\end{array}$ & $\begin{array}{l}\text { To explore patients' } \\
\text { perspective of diabetes, } \\
\text { their experience of tak- } \\
\text { ing oral hypoglycemic } \\
\text { medications and explore } \\
\text { factors that contribute } \\
\text { to medication adher- } \\
\text { ence }\end{array}$ & $13 / 13$ \\
\hline $\begin{array}{l}\text { Agarwala et al (2017), }{ }^{27} \\
\text { India }\end{array}$ & Indian & 28 & $\begin{array}{l}\text { In-depth } \\
\text { interviews }\end{array}$ & Thematic analysis & $\begin{array}{l}\text { To explore reasons for } \\
\text { nonadherence to oral } \\
\text { hypoglycemic agents }\end{array}$ & $12 / 13$ \\
\hline $\begin{array}{l}\text { Mousavizadeh et al (2017), } \\
\text { Iran }\end{array}$ & Iranian & 21 & $\begin{array}{l}\text { Semistructured } \\
\text { interviews }\end{array}$ & $\begin{array}{l}\text { Grounded theory } \\
\text { constant compar- } \\
\text { ative analysis }\end{array}$ & $\begin{array}{l}\text { To explore and under- } \\
\text { stand how adherence } \\
\text { to treatment process } \\
\text { occurs among patients }\end{array}$ & $13 / 13$ \\
\hline
\end{tabular}

Abbreviation: CASP, Critical Appraisal Skills Program.

and shared overarching themes are combined. The consolidated themes from these two studies are then compared and combined with the recurring themes in the third study and so on. In this way, the authors identified, interpreted, and consolidated common themes emerging from the studies. In the event that the authors disagreed about the identification and/ or interpretation of a theme, they re-read the study/studies in question and discussed their point of view until an agreement was arrived at.

After completing translation of the studies into one another, the authors began synthesizing the data by carefully analyzing the first-order interpretations (i.e., patients' perspectives or themes emerged from the study) and the second-order interpretations (i.e., the study authors' interpretations of these themes) to arrive at the third-order interpretation (i.e., the super-ordinate and sub-ordinate themes emerging from the author's analysis). These third-order interpretations were the final synthesized findings of the present meta-ethnography. ${ }^{1}$ - Table 2 describes an example of the first-, second-, and third-order interpretations.

\section{Results}

Three main themes developed from this synthesis: psychological determinants, sociocultural determinants, and patients' relationship with their physicians. Each of these themes will be discussed in turn and the corresponding illustrative quotations are provided in $\mathbf{-}$ Table 3.

\section{Psychological Determinants}

The main psychological factors recurring in all 26 studies of the current meta-ethnography that aided or inhibited patients' diabetes self-management efforts were the patients' locus of control and being forgetful. These are discussed below.

\section{Illness Beliefs}

Illness beliefs was a strong theme that was found in all the studies with beliefs about cause, symptoms, treatment beliefs, and severity or consequences of the illness being the most recurrent themes.

\section{Illness Cause/Control}

Patients who could not identify reasons for having "got" diabetes displayed a lower level of proactiveness than their counterparts, ${ }^{16-19}$ suggesting that not having information about the cause of their illness inhibited patients' abilities to follow their regimen. Most of the studies highlighted that having T2DM-specific knowledge/information (e.g., type of and reasons for engaging in the self-care activities) could promote adherence to the recommended regimen in patients. ${ }^{4,5,19-22}$ 
Table 2 An example of the first-, second-, and third-order interpretations

\begin{tabular}{|c|c|c|c|}
\hline Author details & $\begin{array}{l}\text { First order of } \\
\text { interpretation }\end{array}$ & Second order of interpretation & Third order of interpretation \\
\hline $\begin{array}{l}\text { Agarwala et al27 } \\
(2017)\end{array}$ & $\begin{array}{l}\text { 1. Adverse effects of } \\
\text { weakness, hypoglyce- } \\
\text { mia, organ damage, } \\
\text { vertigo, and fear } \\
\text { 2. Economic issues of cost } \\
\text { of treatment, having } \\
\text { a low income, regular } \\
\text { intake not possible, } \\
\text { acute family crisis } \\
\text { 3. Availability such as } \\
\text { nonavailability of } \\
\text { medicines, living in a } \\
\text { remote place, travel- } \\
\text { ing, same brand is not } \\
\text { available } \\
\text { 4. Alternative treatment } \\
\text { of homeopathy, } \\
\text { Ayurveda, and jari-buti }\end{array}$ & $\begin{array}{l}\text { A. Patients were intimidated by the } \\
\text { high cost of the medication } \\
\text { B. Nonadherent patients displayed } \\
\text { a lack of knowledge, were con- } \\
\text { fused by the dosage, and had } \\
\text { too many tablets to take } \\
\text { C. Side effects of taking the medi- } \\
\text { cation impeded compliance } \\
\text { D. Patients who were forgetful } \\
\text { were nonadherent }\end{array}$ & $\begin{array}{l}\text { A. Sociocultural determinant of financial } \\
\text { issues } \\
\text { B. Diabetes-specific knowledge/ } \\
\text { information. } \\
\text { C. Inness beliefs of treatment } \\
\text { D. Psychological determinant of being } \\
\text { forgetful }\end{array}$ \\
\hline
\end{tabular}

On the other hand, limited or poor knowledge/information about T2DM was associated with patients developing negative beliefs about the illness that was associated with poor adherence. ${ }^{18}$ Interestingly, reduced SMBG was reported by patients who did not have adequate information on the need to engage in monitoring their blood glucose levels, how to interpret the readings, and what to do if the readings were not within the prescribed range. .,18,23 $^{2}$

\section{Symptom Beliefs}

The way patients identified, experienced, and interpreted the symptoms of diabetes was crucial in regulating their self-care behaviors. Patients with asymptomatic conditions, that is, they did not feel any symptoms of diabetes (e.g., tiredness, giddiness, and thirstiness), reported being less adherent to diet, exercise, SMBG, and medication than those who experienced these symptoms, suggesting that patients' beliefs about diabetes-related symptoms guided their adherence. ${ }^{18,20,24-27}$ Indeed, it was observed that patients interpreted the lack of symptoms as an indication that they were "doing it (self-management) right."24; p.466

\section{Treatment Beliefs}

Patients viewed the treatment for diabetes as involving both medical and nonmedical (diet, exercise, SMBG) changes. Patients' beliefs that the prescribed treatment would be effective (e.g., diet would help with better control of their blood sugars) or that the treatment could be invasive or "forever" led to greater adherence. ${ }^{5,19,28,29}$ On the other hand, few studies highlighted that negative perceptions of the treatment led patients not to adhere to them. These negative perceptions primarily came in the form of beliefs that the treatment indicated long-term complications, adverse effects of the treatment methodology (e.g., pin prick to SMBG), and the extent of disruption the treatment would cause to the patient's lifestyle. .1,23,26,30,31 $^{2}$

\section{Severity/Consequences of the Illness}

Of the 24 studies, some observed that the detrimental outcomes of diabetes motivated patients to engage in dietary and medication adherence. ${ }^{2,22,24,29,32-34}$ On the other hand, some studies found that patients felt the serious consequences of diabetes because of the lifestyle changes of diet, exercise, and taking medication they needed to make on an everyday basis. This, in turn, elicited feelings of being "deprived," anger, helplessness, and frustration and a sense of fatalism that may be associated with nonadherence among these patients..$^{28,29,33}$

Interestingly, when patients were prescribed insulin therapy or the dosage was increased, they perceived this to mean that their illness entered a "serious phase."21,22,24 While this induced fear in patients, it also increased their adherence behaviors as they had "nothing to hesitate about...(and) got to be brave to face the facts,"21; p.299 suggesting that patients' emotional response may mediate the relationship between perceptions of disease severity and adherence.

\section{Locus of Control}

Studies that primarily had culturally diverse samples or focused on a specific cultural group found that nonadherence was more prevalent among patients who perceived that the illness, its progression, and complications were outside their control. ${ }^{28,31,35,36}$ Patients who believed that managing diabetes was within their control and abilities often displayed high levels of motivation and self-efficacy to engage in and maintain the recommended treatment. ${ }^{18}$ Further, some studies found that patients with a high internal locus of control regulated their medication based on how they were feeling (e.g., did not take the medication if they 
Table 3 Quotations

\begin{tabular}{|c|c|c|c|}
\hline Main theme & Subtheme & & Quotation \\
\hline \multirow[t]{6}{*}{$\begin{array}{l}\text { Psychological } \\
\text { determinants }\end{array}$} & \multirow[t]{4}{*}{ Illness beliefs } & Illness cause/control & $\begin{array}{l}\text { "Other than exercise, I have gone to one or two diabetic classes to learn } \\
\text { more about a balanced diet for diabetics and I have lost weight in the } \\
\text { past. My biggest change is cutting sweets out. I love sweets, but I have } \\
\text { cut back... very seldom do I have them." } 33 ; \text { p. } 100 \\
\text { "When you monitor it, it's supposed to be between } 4 \text { and } 8 \text {. What I } \\
\text { don't understand is when it jumps up. I know if it goes low, you eat } \\
\text { something to bring it up. What if it goes high, what do you do to bring } \\
\text { it down?"17; p. } 3\end{array}$ \\
\hline & & Symptom beliefs & $\begin{array}{l}\text { "When you monitor it, it's supposed to be between } 4 \text { and } 8 \text {. What I } \\
\text { don't understand is when it jumps up. I know if it goes low, you eat } \\
\text { something to bring it up. What if it goes high, what do you do to bring } \\
\text { it down?"17; p. } 3\end{array}$ \\
\hline & & Treatment beliefs & $\begin{array}{l}\text { "I wouldn't like to take insulin. I know, once on insulin, always on insulin! } \\
\text { And complications occur in patients who take insulin! "6; p. } 633\end{array}$ \\
\hline & & $\begin{array}{l}\text { Severity/consequenc- } \\
\text { es of the illness }\end{array}$ & $\begin{array}{l}\text { "My mother has lost her vision and her kidneys are failing. I know that } \\
\text { those things can happen, but I'm hoping that I'll have a little more } \\
\text { sense, maybe, and get more serious about my diabetes so that I won't } \\
\text { end up losing my limb."32; p. } 34 \\
\text { "No matter how much you take care of yourself, that's gonna happen } \\
\text { (referring to loss of eyesight, foot problems). I was told it's still gonna } \\
\text { happen."22; p. } 126\end{array}$ \\
\hline & Locus of control & & $\begin{array}{l}\text { "Whatever is going to happen is going to happen. My death will come } \\
\text { when it will, it is in Allah's hands." 28; p. } 49\end{array}$ \\
\hline & Being forgetful & & $\begin{array}{l}\text { "I used to think old people were stupid because they couldn't remember } \\
\text { what they did, but, believe me, if you take a lot of tablets, you've no idea } \\
\text { when you've taken them, and what you've taken." } 23 ; \text { p. } 493 \\
\text { "I never stop taking my medications; I take them as a lifestyle similar to } \\
\text { other daily duties. They are a part of my life and I take them routinely } \\
\text { without thinking about it."35; p. } 153\end{array}$ \\
\hline \multirow[t]{3}{*}{$\begin{array}{l}\text { Sociocultural } \\
\text { determinants }\end{array}$} & $\begin{array}{l}\text { Family and com- } \\
\text { munity }\end{array}$ & & $\begin{array}{l}\text { "My married daughter lives in my house and takes care of me. She } \\
\text { makes me feel happy. I never fear going hungry because my daughter } \\
\text { buys food and fills up the fridge..." 36; p.6 }\end{array}$ \\
\hline & Cultural & & $\begin{array}{l}\text { "I felt bad and went off the diet. I went off it because I felt worse than I } \\
\text { should have, and it wasn't. The meals, they were healthy but tasteless, } \\
\text { no fat or flavor, you die of hunger." 1; p. } 763\end{array}$ \\
\hline & Financial & & $\begin{array}{l}\text { "My son lives and works abroad, and he pays for all my medicines. Often } \\
\text { when the money comes late I have to wait to buy my medicines." 34; p. } 136\end{array}$ \\
\hline $\begin{array}{l}\text { Patient-physi- } \\
\text { cian relationship }\end{array}$ & & & $\begin{array}{l}\text { "He (my doctor) is a medical expert. ... He is familiar with my case. ... He } \\
\text { is quite patient and has a caring heart. ... His advices are convincing and } \\
\text { easy to follow." 27; p. } 498 \\
\text { "My anxiety is [because of] the constant scaring by my doctors (laughs) } \\
\text { of the diabetes...that, uh, you're going to lose a leg, you're going to lose } \\
\text { your eyesight." 31; p. } 461 \\
\text { "And I think psychological status is more important than the physical } \\
\text { activity and food regimen. It is even the most important thing in our } \\
\text { lives. Therefore, my doctor must encourage me and give me the hope of } \\
\text { achieving control of my illness, but doesn't do this." } 50 \text {;. } 126\end{array}$ \\
\hline
\end{tabular}

were "in good health" that day) and their dietary intake for the day. $4,5,7,19,32,37$

\section{Being Forgetful}

Another common factor in poor adherence, especially to medication, was patients tended to forget about the treatment. These studies emphasized that this failure to follow the recommended medical regimen was nonintentional and occurred due to a variety of reasons such as being busy, having too many medicines to take, experiencing unforeseen situations, and being asymptomatic. ${ }^{19,23,26,27,37}$ On the other hand, for some patients, medication adherence became second nature, suggesting internalization of the behavior as a technique to prevent forgetfulness..$^{29,35}$

\section{Sociocultural Determinants}

The sociocultural milieu played a pivotal role in patients' adherence or nonadherence. Within these determinants, the 
meta-ethnography found that family, cultural, and financial factors were the most recurrent themes in 14 studies. These will be discussed in the following text.

\section{Family and Community}

Supportive family and community helped patients in their day-to-day management of diabetes. ${ }^{5,6,22,33,36}$ The diagnosis of diabetes brought about a substantial change in the lifestyles of not only the patient but also their family members. This change was particularly experienced in dietary adherence such that patients whose families adjusted their food preferences to match the healthcare provider's recommendation reported better dietary management as compared to those whose families had not changed their food habits to suit the patient's diabetes diet., ${ }^{5,22,29} \mathrm{~A}$ key finding was that male patients frequently reported that their wives/partners managed their diet, ${ }^{2,22}$ and female patients recurrently reported nonadherence in situations when they had to cook separate meals for themselves and their families. ${ }^{6,29}$

Many studies that focused on a specific cultural group highlighted the lack of support from the community (e.g., workplace, social groups, extended family), which led to patients' experiencing stigma. Consequently, patients "hid" the illness to appear "healthy and perfect" that contributed to their inability to adhere as they could not openly engage in self-care practices. $2,6,18,28,29,33$

\section{Cultural}

A major finding was that although patients recognized that following the recommended diet was essential to managing their diabetes, they also perceived food to be a part of their cultural identity and as an integral part of their daily routine. Thus, dietary adherence in particular presented patients with a struggle as the recommendations did not align with their beliefs and habits regarding food. $2,4-6,17,25,36$

\section{Financial}

The financial burden of having diabetes was a recurring theme especially in studies that represented patients from developing countries. ${ }^{19,27,29,34}$ These patients identified that the cost of medication ${ }^{27}$ and delayed financial aid to offset these costs from their immediate family members were reasons for medical nonadherence. ${ }^{34,37}$

\section{Patient-Physician Relationship}

Seventeen studies reported that the healthcare provider, specifically the physician, was a crucial element in shaping the patient's diabetes adherence. The physician had many roles to play. First, patients expected their physician to be competent both medically (e.g., being "familiar" with their case) and relationally (e.g., being able to "convince" patients about the treatment, communicate the "seriousness" of diabetes $)^{17}$; P. 126 Second, physicians had to exhibit a "sympathetic," encouraging and patient manner, especially in terms of providing patients with "all the time they want."31; p. 461
Third, patients wanted their physician to remember their conversations and tended not to disclose their "difficulties" in self-management if a physician "kept on forgetting what they told him." ${ }^{4 ;}$ p. 5 Fourth, physicians were expected to tailor their advice to the patient's needs and circumstances, particularly if the patient was from a different cultural background than their doctor. Thus, culturally congruent support was strongly favored by patients. Finally, patients wanted their physicians to educate them about the required self-care behaviors as well as provide them information on their necessity. Patients whose physicians met these expectations reported better diabetes management than those whose physicians used "scare tactics."

\section{Discussion and Implications}

The current meta-ethnography used the Noblit and Hare's approach to explore T2DM patients' experiences of the factors that facilitated and hindered adherence. ${ }^{12}$ The main themes from the synthesis were (1) psychological determinants (illness beliefs, locus of control, being forgetful), (2) sociocultural determinants (family and community, cultural, financial factors), and (3) the patient-physician relationship.

The psychological determinant of beliefs about diabetes played a key role in patients' (non)adherence. Patients who were able to identify cause of their diabetes, symptoms of diabetes, thought their treatment was effective in managing it, and perceived and/or experienced the negative effects of the illness reported engaging in self-care behaviors. These findings can be explained through the theoretical framework of the Common Sense Model (CSM) of Self-Regulation that suggests that ${ }^{38}$ when faced by a health threat, individuals will form "representations" of the illness experience. These representations (also referred to as perceptions or beliefs) help them make sense of their illness (e.g., symptoms, treatment, timeline) and guide how they respond to the illness (e.g., coping methods). A core feature in CSM-based interventions is their focus on modifying negative illness representations to help chronic disease management. Although there is limited research examining the effectiveness of these interventions on promoting T2DM adherence, some studies evidenced positive results, ${ }^{39}$ especially in SMBG, ${ }^{40}$ and when the intervention was physician-led. ${ }^{41}$ Therefore, it might be worthwhile to develop healthcare provider-led CSM-centric patient education strategies focused on correcting negative beliefs about their causes, symptoms, treatment, and illness consequences.

The psychological determinants of having an internal locus of control facilitated adherence and being forgetful appeared to impede patients' self-management efforts. The former finding supports existing quantitative research that found that having an internal locus of control predicted better diabetes adherence. ${ }^{42}$ The findings of this meta-ethnography revealed that patients with increased levels of internal locus of control relied on their daily personal experiences of diabetes and regulated their medication and diet accordingly. This suggests possibilities of highly self-confident patients being nonadherent since they may depend on how they were feeling at 
that time which is, in reality, dynamic and has a greater tendency to deviate from a routine. Further, limited quantitative studies examined the role of forgetfulness in diabetes adherence, ${ }^{43,44}$ thus highlighting the importance of using a qualitative approach that delves into lived experiences. In the current meta-ethnography, it was observed that reasons for being forgetful were that patients were either busy, encountered unexpected circumstances, or did not have any symptoms to remind them. It is interesting to note that experiencing the symptoms of diabetes were common to both the psychological determinants of local of control and forgetfulness to regulate better adherence, highlighting the need to educate patients' understanding of, ability to register/recognize and identify appropriate reactions to diabetes-related symptoms. Overall, these findings indicate the need for healthcare providers to have a communicative relationship with patients such as helping set regular reminders and ascertaining patients' locus of control to encourage/guide them accordingly.

Family support was a determinant primarily in dietary adherence, such that families who adjusted to the changed dietary requirements may have aided in patients' adherence and vice-versa. On the other hand, patients who felt they were not supported by their communities reported that they were unable to openly engage in self-care behaviors which, they believed, obstructed their adherence. In line with quantitative research, ${ }^{45,46}$ this finding underlines the central role that food and community support play in patients' daily efforts toward adherence. A striking finding was that women were considered to be the gatekeepers of the kitchen such that male patients reported that their wives/partners looked after their diet and female patients were often found to be nonadherent when they had to cook a separate diabetes-appropriate meal for themselves. This indicates that caregivers and patients who are female need to be educated about the importance of the role of diet in maintaining blood glucose levels. Further, healthcare providers need to explore dietary behaviors among women with T2DM and problem-solve any barriers to adherence that they may be facing (e.g., including the primary family member during diet counseling, providing families with diabetes-related psychoeducation).

The significance of food was particularly evident in the current meta-ethnography wherein patients reported that eating their preferred types of food was an expression of their cultural identity and not being able to follow their favored diet was viewed with displeasure and/or as a deviation from their culture/roots. Therefore, future research needs to further unpack the deeper, subjective meaning(s) that food holds for patients with T2DM as this may inform the development of tailored dietary education interventions. This may be particularly useful for patients whose culturally embedded dietary choices consisted of high glycemic index foods as they may benefit from practical support from their healthcare provider (e.g., educate patients on portion control such that they could have small but satisfying meals). Further, the financial burden of diabetes was a strong theme among patients from developing countries with medication cost and delayed monetary assistance described as primary reasons for nonadherence. As evidenced by quantitative research ${ }^{47}$ providing health insurance to patients can help offset these financial pressures. Moreover, as part of a public health policy effort, patients from developing countries might be routinely provided financial planning/advice to better manage their monetary needs, thus perhaps aiding in following their recommended medical regimen.

Patients had several expectations about how their physician should behave that were related to their abilities/willingness to adhere. In spite of the overwhelming importance of the patient-physician relationship, only one quantitative study investigated the link between physicians' interactive skills and patients' glycemic control. ${ }^{48}$ The authors reported that when physicians engaged in a collaborative education style, patients had better adherence. A key limitation of this study, however, was that it examined only one aspect of physician communication skills, that is, information-sharing. As shown by the current qualitative synthesis findings and prior literature reviews, ${ }^{49}$ physician communication skills need to also be centered on developing an empathetic and personal relationship with the patient so that it leads to increased involvement, commitment, and understanding with the ultimate goal of improved T2DM adherence. Therefore, future research will benefit from developing and testing communication skills training for physicians dealing with patients with T2DM that can, in turn, inform public health policy around physicians' skills.

\section{Methodological Considerations}

The current meta-ethnography aimed to explore barriers and facilitators of T2DM adherence from exclusively the patients' perspectives since they were at the center of the diabetes experience. Based on the findings of the current synthesis, it may be beneficial for future meta-ethnographies to take into consideration the role and experiences of multiple stakeholders (e.g., family caregivers, physicians) in the process of adherence. Further, some research suggest that meta-synthesis findings may be able to generalize qualitative findings. ${ }^{15}$ The current meta-ethnography used Noblit and Hare's method of reciprocal translation that aids in integrating individual study findings iteratively so as to develop overarching themes while not losing the "thickness" of the data, thus establishing that a qualitative synthesis adds to our knowledge of the individual experience.

\section{Conclusion}

This meta-ethnography identified a range of facilitators and barriers to T2DM adherence among patients, providing useful insights into the lived experience of diabetes from patients' perspectives. The findings of this qualitative synthesis help explain poor patient adherence as well as factors that aid in adherence, including patients' levels of diabetes knowledge, illness beliefs, psychological determinants, sociocultural determinants, and patients' relationship with their physicians. The current meta-ethnography supports the 
need to include qualitative research methods to develop and test interventions so they are appropriate and personalized for the patient and the target behavior (e.g., CSM-centric education interventions).

\section{Funding}

This research work was funded through a PhD fellowship awarded to the lead author by the Ministry of Human Resource Development, Government of India.

\section{Conflict of Interest}

None declared.

\section{References}

1 Shultz JA, Sprague MA, Branen LJ, Lambeth S. A comparison of views of individuals with type 2 diabetes mellitus and diabetes educators about barriers to diet and exercise. J Health Commun 2001;6(2):99-115

2 Castro-Sánchez AE, Ávila-Ortíz MN. Changing dietary habits in persons living with type 2 diabetes. J Nutr Educ Behav 2013;45(6):761-766

3 Praet SFE, van Rooij ES, Wijtvliet A, et al. Brisk walking compared with an individualised medical fitness programme for patients with type 2 diabetes: a randomised controlled trial. Diabetologia 2008;51(5):736-746

4 Vermeire E, Royen PV, Coenen S, et al. The adherence of type 2 diabetes patients to their therapeutic regimen: a qualitative study. Pract Diabetes Int 2003;20(6):209-214

5 Vinter-Repalust N, Petricek G, Katić M. Obstacles which patients with type 2 diabetes meet while adhering to the therapeutic regimen in everyday life: qualitative study. Croat Med J 2004;45(5):630-636

6 Vermeire E, Hearnshaw H, Rätsep A, et al. Obstacles to adherence in living with type-2 diabetes: an international qualitative study using meta-ethnography (EUROBSTACLE). Prim Care Diabetes 2007;1(1):25-33

7 Sohal T, Sohal P, King-Shier KM, Khan NA. Barriers and facilitators for type-2 diabetes management in South Asian: a systematic review. PLoS One 2015;10(9):e0136202

8 Gomersall T, Madill A, Summers LK. A meta-synthesis of the self-management of type 2 diabetes. Qual Health Res 2011;21(6):853-871

9 Gask L, Macdonald W, Bower P. What is the relationship between diabetes and depression? A qualitative meta-synthesis of patient experience of co-morbidity. Chronic Illn 2011;7(3):239-252

10 Fleming E, Gillibrand W. An exploration of culture, diabetes, and nursing in the South Asian community: a meta-synthesis of qualitative studies. J Transcult Nurs 2009;20(2):146-155

11 Chen CM, Chang Yeh M. The experiences of diabetics on self-monitoring of blood glucose: a qualitative meta-synthesis. J Clin Nurs 2015;24(5-6):614-626

12 Noblit GW, Hare RD, Meta-Ethnography: Synthesizing Qualitative Studies. Neubury Park, California: Sage Publication; 1988

13 Britten N, Campbell R, Pope C, Donovan J, Morgan M, Pill R. Using meta ethnography to synthesise qualitative research: a worked example. J Health Serv Res Policy 2002;7(4):209-215

14 Campbell R, Pound P, Pope C, et al. Evaluating meta-ethnography: a synthesis of qualitative research on lay experiences of diabetes and diabetes care. Soc Sci Med 2003;56(4):671-684

15 Atkins S, Lewin S, Smith H, Engel M, Fretheim A, Volmink J. Conducting a meta-ethnography of qualitative literature: lessons learnt. BMC Med Res Methodol 2008;8:21

16 Tan PSX, Chen HC, Taylor BJ, Hegney DG. Exploring the meaning of hypoglycaemia to community-dwelling Singaporean
Chinese adults living with type 2 diabetes mellitus. Int J Nurs Pract 2012;18(3):252-259

17 Greenhalgh T, Helman C, Chowdhury AM. Health beliefs and folk models of diabetes in British Bangladeshis: a qualitative study. BMJ 1998;316(7136):978-983

18 Peel E, Douglas M, Lawton J. Self monitoring of blood glucose in type 2 diabetes: longitudinal qualitative study of patients perspectives. BMJ 2007;335(7618):493-498

19 Al-Qazaz HK, Hassali MA, Shafie AA, Syed Sulaiman SA, Sundram S. Perception and knowledge of patients with type 2 diabetes in Malaysia about their disease and medication: a qualitative study. Res Social Adm Pharm 2011;7(2):180-191

20 Lawton J, Ahmad N, Hallowell N, Hanna L, Douglas M. Perceptions and experiences of taking oral hypoglycaemic agents among people of Pakistani and Indian origin: qualitative study. BMJ 2005;330(7502):1247

21 Lai WA, Chie WC, Lew-Ting CY. How diabetic patients' ideas of illness course affect non-adherent behaviour: a qualitative study. Br J Gen Pract 2007;57(537):296-302

22 Sherman LD, McKyer ELJ, Singer JN, et al. Understanding the essence and lived experience of self-care management among African-American men living with type 2 diabetes. J SocHealth Diabetes. 2014;2(2):96

23 Lawton J, Peel E, Parry O, Douglas M. Patients' perceptions and experiences of taking oral glucose-lowering agents: a longitudinal qualitative study. Diabet Med 2008;25(4):491-495

24 Brown K, Avis M, Hubbard M. Health beliefs of African-Caribbean people with type 2 diabetes: a qualitative study. $\mathrm{Br} \mathrm{J}$ Gen Pract 2007;57(539):461-469

25 Washington G, Wang-Letzkus MF. Self-care practices, health beliefs, and attitudes of older diabetic Chinese Americans. J Health Hum Serv Adm 2009;32(3):305-323

26 He W, Zhang Y, Zhao F. Factors influencing exercises in Chinese people with type 2 diabetes. Int Nurs Rev 2013;60(4):494-500

27 Agarwala S, Ansari A, Paul UK, et al. A qualitative study on non-adherence to oral hypoglycemic agents in type 2 diabetics. IntJ Adv Med. 2017;4(4):1099-1102

28 Lawton J, Ahmad N, Hanna L, Douglas M, Hallowell N. 'I can't do any serious exercise': barriers to physical activity amongst people of Pakistani and Indian origin with Type 2 diabetes. Health Educ Res 2006;21(1):43-54

29 Shakibazadeh E, Larijani B, Shojaeezadeh D, Rashidian A, Forouzanfar M, Bartholomew L. Patients' perspectives on factors that influence diabetes self-care. Iran J Public Health 2011;40(4):146-158

30 Peel E, Parry O, Douglas M, Lawton J. Blood glucose self-monitoring in non-insulin-treated type 2 diabetes: a qualitative study of patients' perspectives. $\mathrm{Br} \mathrm{J}$ Gen Pract 2004;54(500):183-188

31 Kokanovic R, Manderson L. Exploring doctor-patient communication in immigrant Australians with type 2 diabetes: a qualitative study. J Gen Intern Med 2007;22(4):459-463

32 Matthews SM, Peden AR, Rowles GD. Patient-provider communication: understanding diabetes management among adult females. Patient Educ Couns 2009;76(1):31-37

33 Rustveld LO, Pavlik VN, Jibaja-Weiss ML, Kline KN, Gossey JT, Volk RJ. Adherence to diabetes self-care behaviors in Englishand Spanish-speaking Hispanic men. Patient Prefer Adherence 2009;3:123-130

34 Islam SMS, Biswas T, Bhuiyan FA, Mustafa K, Islam A. Patients' perspective of disease and medication adherence for type 2 diabetes in an urban area in Bangladesh: a qualitative study. BMC Res Notes 2017;10(1):131-139

35 Mousavizadeh SN, Ashktorab T, Ahmadi F, Zandi M. From negligence to perception of complexities in adherence to treatment process in people with diabetes: A grounded theory Study. Iran J Med Sci 2018;43(2):150-157 
36 Boonsatean W, Dychawy Rosner I, Carlsson A, Östman M. Women of low socioeconomic status living with diabetes: becoming adept at handling a disease. SAGE Open Med 2015;3:2050312115621312

37 Paduch A, Kuske S, Schiereck T, et al; Joint Action on Chronic Diseases and Promoting Healthy Ageing across the Life Cycle (JA-CHRODIS). Psychosocial barriers to healthcare use among individuals with diabetes mellitus: a systematic review. Prim Care Diabetes 2017;11(6):495-514

38 Leventhal $\mathrm{H}$,BrissetteI, LeventhalEA, The common-sense model of self-regulation of health and illness. The self-regulation of health and illness behavior. 1st ed. London: Routledge; 2003: 42-65

39 Harvey JN, Lawson VL. The importance of health belief models in determining self-care behaviour in diabetes. Diabet Med 2009;26(1):5-13

40 Breland JY, McAndrew LM, Burns E, Leventhal EA, Leventhal H. Using the Common Sense Model of Self-regulation to review the effects of self-monitoring of blood glucose on glycemic control for non-insulin-treated adults with type 2 diabetes. Diabetes Educ 2013;39(4):541-559

41 Phillips LA, Leventhal H, Leventhal EA. Physicians' communication of the common-sense self-regulation model results in greater reported adherence than physicians' use of interpersonal skills. Br J Health Psychol 2012;17(2):244-257

42 Tillotson LM, Smith MS. Locus of control, social support, and adherence to the diabetes regimen. Diabetes Educ 1996;22(2):133-139
43 Shrestha SS, Shakya R, Karmacharya BM, Thapa P. Medication adherence to oral hypoglycemic agents among type II diabetic patients and their clinical outcomes with special reference to fasting blood glucose and glycosylated hemoglobin levels. Kathmandu Univ Med J (KUMJ) 2013;11(43):226-232

44 Jackson IL, Adibe MO, Okonta MJ, Ukwe CV. Medication adherence in type 2 diabetes patients in Nigeria. Diabetes Technol Ther 2015;17(6):398-404

45 Irvine AA, Saunders JT, Blank MB, Carter WR. Validation of scale measuring environmental barriers to diabetes-regimen adherence. Diabetes Care 1990;13(7):705-711

46 Wen LK, Shepherd MD, Parchman ML. Family support, diet, and exercise among older Mexican Americans with type 2 diabetes. Diabetes Educ 2004;30(6):980-993

47 Ngo-Metzger Q, Sorkin DH, Billimek J, Greenfield S, Kaplan SH. The effects of financial pressures on adherence and glucose control among racial/ethnically diverse patients with diabetes. J Gen Intern Med 2012;27(4):432-437

48 Schillinger D, Piette J, Grumbach K, et al. Closing the loop: physician communication with diabetic patients who have low health literacy. Arch Intern Med 2003;163(1):83-90

49 Sridharan SG, Chittem M, Muppavaram N. A review of literature on diabetes self-management: Scope for research and practice in India. J Soc Health Diabetes. 2016;4(2):108-114

50 Zamzam S, Anoosheh M, Ahmadi F. Barriers to diabetes control from Syrian women's perspectives. Jpn J Nurs Sci 2013;10(1):121-129 